\title{
The State Of Teaching Accounting Information Systems: Is There A Gap?
}

Roger K. Doost, (E-mail: droger@clemson.edu), Clemson University Gary B. McCombs, (E-mail: gary.mccombs@emich.edu), Eastern Michigan University Mohsen Sharifi, (E-mail: msharifi@fullerton.edu), California State University Fullerton

\begin{abstract}
Based upon a literature review and through interviews, discussions, and questionnaires filled out by accounting information systems (AIS) educators, the authors conclude that while total consistency and uniformity may not be desirable in teaching the subject of AIS, there seems to still be a need for more rigor, more consistency in coverage, and perhaps, more cutting-edge training of instructors to be able to prepare the students in this important area. They further conclude that more hands-on exercises and practice seem to be needed in the dissemination of knowledge in this respect. The authors also observe that perhaps more than one course is needed to be able to cover the fundamentals in accounting systems as well as provide numerous experiences with relevant software. Additional interviews and discussions with experts in the accounting systems area on an ongoing basis are very much needed to do justice to this important matter.
\end{abstract}

\subsection{Introduction}

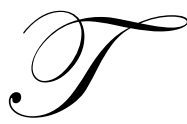

he theme of a number of papers presented in the first Accounting Information Systems (AIS) Educators' Conference in 1999 in Denver, Colorado, was the perceived gap between what educators consider to be significant in teaching the accounting information systems courses versus the perception of professionals. This theme was repeated in various formats in the following years, and in the Third Conference a survey of educators on the subject was also conducted. The results of the survey were posted on the AIS Educators' conference website [AIS Educators' 2001]. Several authors also have pointed out the apparent discrepancy in the evaluations that they receive when they teach AIS courses as compared to other accounting courses. The above factors are motivating forces behind this study.

\subsection{Questions Asked}

We felt compelled to ask these questions more rigorously in the following manner and benefit from the surveys that our colleagues have conducted in addressing these issues in their recent work.

- Is traditional pedagogy still relevant for teaching AIS topics?

- $\quad$ Do all accounting programs offer at least one AIS course?

- $\quad$ Are the contents of the AIS course the same?

- Is it possible to conduct a uniform competency test and achieve satisfactory results in a single AIS course?

- $\quad$ Is a single AIS course sufficient to satisfy the professional skills needed from professional accountants?

- What AIS topics are essential and should be covered?

- $\quad$ Should the AIS topics be standardized in a manner similar to other accounting subjects such as, financial accounting, tax accounting, and auditing?

- $\quad$ Should more courses be devoted to AIS subjects?

- What would be the impact on faculty training and development in the short-run and in the long-run?

- $\quad$ Does the basic AIS course prepare students for the next level of competencies?

Readers with comments or questions are encouraged to contact the author via email. 


\subsection{Changes in the Environment}

To address these issues, we must be cognizant of the growing internationalization of businesses, as multinational firms are functioning all across the globe. Electronic media, electronic commerce and widespread use of the internet have facilitated interchange of goods and services while at the same time causing further challenges and complications for the accountant in recording and auditing transactions in the global market. Accounting firms have been transformed into providers of traditional tax and accounting services as well as consulting and information design providers. The consulting and information design functions, however, will likely be subject to reorganization rules as a result of recent audit failures. On an international level, the advent of the computer and the explosion of the internet have provided opportunities and threats - opportunities for instant communication, global interaction, exchange and communication, and threats for those who have or are falling behind in terms of the use and application of the new techniques in education, industries and services. This acceleration has also threatened the previously much slower pace in communication, manufacturing, and information processing. As a result, the gap between the rich and poor nations as well as the rich and poor in every society has widened substantially to a level that could jeopardize regional and global stability.

Delivery methods of the subject matter have dramatically changed. Most schools are equipped partially or totally with smart classrooms as well as several computer labs with easy access to several software packages, including the Microsoft Office family or similar software. Specialized software in various disciplines is more readily available. Topical and specialized searches of topics through the medium of the internet have become commonplace.

Both within the profession, as well as in academia, more specialization in the areas in which we work or teach has become prevalent. Many schools offer specialized courses or seminars in the use of the internet, in several applications' software and in database management. Students have taken a keener interest in one or several applications and have been able to either be self-taught or have developed basic knowledge with the assistance of professors or other students.

Most of the above factors and changes have had profound impact on the structure of the accounting curriculum, as has been well documented by issuance within the accounting discipline of the Bedford Committee report [AAA 1986], the White Paper [Arthur Andersen et. al. 1989], the Accounting Education Change Commission [AECC 1990] report and the Albrecht and Sack study [2000]. The issues addressed above have had even greater impact on the AIS courses, their contents and the way they are taught in business schools. This impact has articulated itself in the form of wide variations in practices in AIS teaching materials, pedagogy and the variety of subject matter covered. Unfortunately, this same observation was made twenty years ago and the problem continues [Wu 1983].

To bring some type of convergence to this varied practice, organizational leadership is needed. Thus, to provide reasonable answers to some of the questions asked earlier, we need to study the leadership provided to the AIS area in the past three decades within the broader discipline of accounting first. Then we consider options available to take the AIS area to a higher level. We hope the AIS educator community would provide appropriate answers to all the questions asked earlier through their research efforts.

The American Accounting Association, as the premier organization for accounting educators, has appointed several committees to investigate, evaluate and recommend appropriate courses of action to AIS (Accounting and Information Systems prior to 1980s). The following sections outline a few of these efforts.

\subsection{Committee on the Role of the Computer in Accounting Education}

The Committee Report, dated 1968-69, of the Committee on the Role of the Computer in Accounting Education concluded that in order for accounting students who are the future accounting professionals to keep pace with technology, students must a) learn a basic programming language and write a simple program, b) be able to incorporate computer problems into the accounting subject matter, and c) have coverage of electronic data 
processing as one of the aids to accounting. This mandate was far more advanced than the earlier mindset among accounting educators and professionals, who considered computers to be the domain of computer experts, and accountants to be mere users of technology. The term auditing around the computer was coined meaning that because we are not aware of what goes on within the computer system, the accountant's audit should be based on readable input and readable output, thus virtually ignoring the essentials of processing and transformation. The current mandate was a beginning, but a far cry from the difficulties and tribulations that accountants were encountering and were soon to encounter on a much larger scale due to their ignorance of the new technology that was leading the way and leaving the resisters to change in the dust.

\subsection{Report of the Committee on Information Systems}

The 1972 Committee on Information Systems was assigned with the charge to "assess the developments that are likely to occur over the next 10 years that will have a significant impact on the design and operation of information systems..." [AAA 1972, p. 189] The Committee was asking certain key questions in handling this important mandate. What is the role of fiscal administrators? What technologies are forthcoming? What are the educational implications? What should AAA do?

The Committee concluded at the time that defining an accounting information systems program would be ill-advised [AAA 1972, p. 207], particularly with respect to the incorporation of information systems material into accounting curricula. Instead it reported that the Committee would make an effort in predicting the impact of various developments on accounting information systems education. No specific recommendations were offered. If we can think of lost opportunities, this was definitely one of them - and a vital one at that. The profession could not afford to wait another couple of years to send out questionnaires, process the data collected and report the results of those findings. The profession was already way behind in the use and application of those resources. The educators, the professionals and the students in the field of accountancy were severely handicapped by this lack of action, and the absence of a clear mandate and direction.

\subsection{Committee on Contemporary Approaches to Teaching Accounting Information Systems}

This Committee of the American Accounting Association, referred to as the Mock Committee [AAA 1987], was formed with a more clear charge: a) identify problems of teaching AIS, and b) propose ways and means of dealing effectively with these problems.

The Committee Report that was issued in 1987 and was by far the most comprehensive work in the area of AIS by an AAA committee. The report took an inventory of the forty issues or subject matters in teaching the first AIS course and summarized them into four main issues. The Committee then concluded that a) students are given a non-homogeneous set of instructions/information in AIS, b) remedial instruction for existing faculty and students is essential, c) a new (revised) set of output objectives for the AIS course is necessary, and d) lack of qualified faculty, inadequate hardware and software, and inappropriate pedagogy are serious handicaps that need to be dealt with. Along the same line, four expertise levels were identified: a) IS user, b) IS auditor, c) IS designer, and d) IS evaluator. Other recommendations from the report suggested that the first AIS course must be taken at the junior level. Thus, the first course should serve as a prerequisite for other AIS courses such as AIS Auditing and Systems Analysis and Design.

Bloom's taxonomy [Bloom 1956] was suggested in identifying knowledge, comprehension level, application, analysis, synthesis and evaluation for the course in AIS. The suggested AIS content was to be composed of the nine areas of: 1) database concepts, 2) internal control, 3) technology of information systems, 4) user of systems technology, 5) AIS applications, 6) management use of information, 7) management of information systems, 8) systems analysis and design, and 9) auditing of AIS. According to the Committee, such course content would meet the core requirements for students preparing for a career involving any of the four roles identified above. The Committee also concluded that other further objectives would be met in an advanced course and through work experience. 
The Committee recognized that those who do not have elementary computer literacy should take remedial action. Then the Committee recommended a proposed degree of coverage for the nine areas mentioned above. However, the coverage ratings for the topics and amount of coverage in the course were based on consensus and not unanimity of the Committee members. Therefore, in some cases, the coverage ratings do not appear to be consistent with the recommended level of coverage stated in the report. Second, it appears that the textbooks listed in the report did not cover all the nine areas. Third, no concrete set or sets of materials were offered for teaching an AIS course, and finally, it was not clear whether or not the gap between the materials available, based on the current course scope, and the desired knowledge demanded by employers of graduates had increased or decreased.

\subsection{Calderon's Findings and International Federation of Accountants (IFAC)}

Calderon et. al. [2002] provide an examination of the current state of accounting information systems' education. They provide an assessment of the current AIS in the United States and present two sets of guidelines available for AIS education. First the American Institute of Certified Public Accountants (AICPA) G 11 standard [AICPA 2000], initially created by the Education Committee of the International Federation of Accountants [IFAC 1998] and the second, the Information Systems Audit and Control Association (ISACA) model curriculum that provides a list of courses that are prescribed as minimum skills needed in information systems auditing [ISACA 2000].

Calderon et. al. survey both undergraduate and master's programs of The International Association for Management Education (still better known as AACSB) accredited programs in accounting and reported that the "traditional absence of a focused, coherent attempt to develop and promote accounting information systems as an academic discipline may be one of the critical factors that contributes to the slow diffusion of AIS programs in business schools" [Calderon et. al. 2002, p. 29]. Moreover, only a small number of AIS programs are part of programs that have separate AACSB accounting accreditation, and there are only a smaller number of programs that incorporate curriculum ideas from AICPA and ISACA.

IFAC through its Guideline 11 (IEG 11) [IFAC 1998] suggested that there must be essential coverage of information technology in the accounting curriculum, and identified three roles beyond a user: designer, manager, and evaluator. The proposed coverage by IEG 11 assumes "pre-qualification" and "post qualification" stages. For pre-qualification, the guidelines suggest four courses: two foundation courses, one term to overview the user role, and a one term specialization for those seeking to be a designer, a manager, or an evaluator of AIS. IEG 11 also recommended post-qualification knowledge acquisition in the form of Continuing Professional Education (CPE).

\subsection{The AICPA's Core Competencies}

The AICPA's Core Competencies are those skills recommended as a minimum set of skills desired for entry into the accounting profession. These competencies are in the form of on-line resources available to all interested parties. As of February 2002, three groups of functional, personal, and broad business perspective competencies are stated [AICPA 2002]. Among these three broad groups, they further identify many elements within each group. The authors have identified 53 elements that seemingly impact AIS courses. These elements are listed in Table 1. Then the authors have classified the competencies into the sub-areas that are relevant to and impact on AIS courses. The number of elements relevant to each sub-area are also identified in the form of the following tabulation:

It appears that most of the above competencies are presently covered in typical AIS courses. However, the depth of the coverage is different depending on the instructor's choice and the material available. The coverage of project management is often lacking. The review of these elements suggests that "team" competencies may be covered in the other project oriented courses. Furthermore there does not seem to be much emphasis on data modeling skills. Seemingly, this skill may have been integrated into the design elements which are listed above. 


\begin{tabular}{|lc|}
\hline Area & No. of Elements \\
\cline { 2 - 2 } System design & $(4)$ \\
Analysis & $(2)$ \\
Output design & $(11)$ \\
Implementation/project management & $(10)$ \\
Strategy and decision making & $(5)$ \\
Technology & $(4)$ \\
Internal control/risk/security & $(5)$ \\
Data modeling & $(2)$ \\
Teams & $(7)$ \\
Ethics & $(2)$ \\
\hline
\end{tabular}

\subsection{AIS Educators' Survey}

The AIS Educators' Conference Survey was conducted during the 2001 Conference. Ninety-eight of the participants completed a short survey. The response rate was 59 percent and the results were posted on the Conference website [AISEC 2001]. This survey shows that the typical AIS course is offered at the junior level, that a great majority of programs blend the coverage of transaction cycles and/or business processes, and finally that many educators state the lack of class time available for using appropriate software. This finding is significant, because it is obvious that the study of such highly technical material without inclusion of appropriate software to enhance learning could be a potential problem that educators may have to confront in the not too distant future - yet again.

\section{Survey of Textbooks}

The authors reviewed eleven AIS textbooks with the highest frequency of use among the educators who responded to the AIS Educators' Conference survey. They include Bodnar [2001], Broockholdt [1999], Bragg [2001], Gelinas [2002], Hall [2001], Hollander [2000], Moscove [2001], Murthy [1997], Perry [2001], Romney [2000] and Wilkinson [2000]. The survey results are reflected in Table 2.

Table 2 is prepared based on the AIS Educators' responses provided by the individuals attending the 2001 Conference. The top ten topics ranked in the survey are listed first; the highest score of 3.55 (out of 5) is assigned to data flow diagrams and 3.34 to the tenth topic, systems design. In the next two columns the maximum number of pages dedicated to those topics in the textbooks reviewed and the number of the texts that cover the topics are listed. For instance, data flow diagrams are mentioned in only seven of the eleven textbooks. In many cases the minimum pages devoted to a particular topic were one to two pages. This lack of consensus among the authors and coverage of different topics at different lengths was also noted a long time ago by $\mathrm{Wu}$, who said, "A problem faced by many AIS instructors is that accounting academicians do not agree on which subjects should be taught in the AIS course. This lack of agreement is aggravated by a variety of AIS textbooks covering different topics at different lengths" [Wu 1983, pp. 132-133]. The authors could not determine precisely what the number of pages allocated to a "computer-based practice set" was and what the extent of the coverage of that in each textbook was. In the lower part of Table 2, the emerging AIS topics suggested by the educators attending the 2001 Conference and other sources are listed. The authors acknowledge that their counts of matching page numbers are subjective based on the authors' interpretation of the topic meaning.

All the textbooks are seemingly written for the first AIS course, but in most cases it is not clear who the target audience is (junior, senior or graduate). A few authors have mentioned their target audience in the preface to their books. Some authors have provided advanced topics, considering the target audience, such as strategy and value chain in their introductory chapters. Cases and problems in some books often assume prior knowledge of the subject matter that may not have been presented to the students at this stage of the curriculum - particularly those selected from professional examinations that cover internal control and system design topics.

Different styles in presentation and methodology make it difficult to determine the degree of importance placed on topics presented. This variation could be the result of marketing decisions by the publishers. Some materials are placed in the appendices of chapters by some authors while others cover them in the body of the text. Some texts offer computer skills out of custom published materials. Instructors often pick and choose topics to teach, and this further adds to the lack of uniformity in coverage of material and importance placed on each topic by the authors. 
In general, we observed that certain topics such as systems analysis and design and database are pushed toward the ending chapters of the texts. Furthermore, clear gaps exist in the areas of process flowcharting, business process reengineering and management use of information systems. Finally, we need to address the problems with conformity (or lack of same) with prescribed material based on the textbook author's or instructor's preferences.

\section{Conclusion and Future Directions}

Referring to the questions asked earlier, at this point, we are not certain which pedagogy is more appropriate for the first AIS course. AIS educators by and large employ the pedagogy that they feel comfortable with. The AIS subject appears to be different from the traditional accounting subjects such as taxation, cost, etc. Thus, it requires more interaction with computerized systems. We do not recommend any specific pedagogy at this time. The review of different surveys and interaction with our colleagues in various conferences have shown that AIS educators for the most part are comfortable with the effectiveness of their own pedagogy. We have observed more sharing of resources among AIS Educators' Conference papers and presentations than other areas of accounting. Thus, we believe the appropriate pedagogy will evolve as a result of continuous interactions among educators. This lack of concrete pedagogy may be responsible for lower instructors' ratings in AIS courses.

Do all accounting programs offer at least one AIS course? The answer is affirmative, particularly for accredited programs. It is obvious many schools consider AIS as an essential skill included in the common body of accounting knowledge for the specialized tracks they offer. However, information in Table 2 demonstrates the contents of AIS courses offered are varied based on the degrees of importance placed on each topic by the educators. Our study of the relevant literature on AIS textbooks demonstrates a widespread gap between what the profession demands, as specified in the AICPA Core Competencies, and what we offer at institutions of higher learning. It is not the intention of the authors to sanction any degree of rigidity in the way and the manner that AIS topics covered. Nevertheless, we believe that this is a very important matter. Thus, the essential coverage expected is important enough that the profession may want to demand that authors and instructors put proper weight and cover some mandated essentials in the area in spite of the possible uproar regarding academic freedom. Unless some measures are taken by the AIS educators to specify the common topics and a minimum depth of coverage, it would not be possible to achieve an acceptable degree of satisfaction when assessing the competencies desired for an AIS course.

The next question is what topics should be included in a single AIS course? We recommend a combination of the highly rated topics in Table 2 and the topics suggested by the Mock Committee. One may find a certain degree of overlap between these two sources. Nevertheless, this approach will allow some standardization of the topics and more convergence in teaching practice by AIS educators. At the same time, non-conformity may be necessary where qualified instructors are on the cutting edge and could introduce innovative content and coverage that others may benefit from in the years to come.

One thing that is clear is that there is not enough time to cover all the essential materials in a single AIS course. This is evident by the variety of topics covered in a typical AIS course. In many cases the instructors may have to prioritize and choose among competing topics. Although some accounting programs offer up to four additional AIS courses, the titles of those courses clearly indicates that they are dealing with more specialized areas of AIS such as information systems audit, database design and e-business. We believe a second AIS course could be developed totally dedicated to the emerging issues of AIS and even deeper coverage of materials covered in the first course. Due to the nature of changes in information technology, it may be imperative to create a separate course. This course should in no way be used to teach specialized topics such as IS audit.

We believe AIS educators are in the best position to assess the issue further and organize the courses in a customer focused manner. This will be possible only by studying and addressing the real needs of the employers of the AIS graduates. Of course, we believe that the resources requirement would be an issue in pushing such a proposal. However, it appears that the benefits received from promoting AIS courses and programs, as evidenced by demand for such AIS graduates, would far outweigh the costs of creating more courses and faculty development. 


\section{References}

1. American Accounting Association (AAA), Committee on the Role of the Computer in Accounting Education, "Report of the 1968-69 Committee on the Role of the Computer in Accounting Education," The Accounting Review (Supplement to Volume XLV), pp. 29-44, 1970.

2. American Accounting Association (AAA), Committee on Information Systems, "Report of the Committee on Information Systems," The Accounting Review (Supplement to Volume XLVII), pp. 186-213, 1972.

3. American Accounting Association (AAA), Committee on the Future Structure, Content, and Scope of Accounting Education (The Bedford Committee), "Future Accounting Education: Preparing for the Expanding Profession," Issues in Accounting Education, Vol. 1, No. 1, pp.168-195, spring 1986.

4. Accounting Education Change Commission (AECC), "Objectives of Education for Accountants: Position Statement Number One," Issues in Accounting Education, Vol. 5, No. 2, pp. 307-312, Fall 1990.

5. Accounting Information Systems Educator Conference (AISEC), Results of Survey of Participants, Third Annual Conference, http://www.ais-edu.com/survey\%20results.htm, 2001.

6. American Institute of Certified Public Accountants (AICPA), Information Technology Competencies in Accounting Curriculum, http://aicpa.org/members/div/infotech/itc/index.htm, 2000.

7. American Institute of Certified Public Accountants (AICPA), Core Competency Framework for Entry into the Accounting Profession, http://aicpa.org/edu/corecomp.htm, 2002.

8. Albrecht, W. Steve and Robert J. Sack, Accounting Education: Charting the Course through a Perilous Future, Accounting Education Series, Vol. 16, Sarasota, FL: American Accounting Association, August 2000.

9. $\quad$ Arthur Andersen \& Co., Arthur Young, Coopers \& Lybrand, Deloitte Haskins \& Sells, Ernst \& Whinney, Peat Marwick Main \& Co., Price Waterhouse, and Touche Ross, Perspectives on Education: Capabilities for Success in the Accounting Profession, April 1989.

10. Bloom, B. S., Taxonomy of Educational Objectives: The Classification of Educational Goals, Handbook I: Cognitive Domain, Longman, New York, 1956.

11. Bodnar, George H., and William S. Hopwood, Accounting Information Systems, 8th Edition, Prentice Hall, Upper Saddle River, New Jersey, 2001.

12. Boockholdt, J. L., Accounting Information Systems, 5th Edition, McGraw-Hill/Irwin, New York, 1999.

13. Bragg, Steven M., Just-In-Time Accounting: How to Decrease Costs and Increase Efficiency, John Wiley \& Sons, New York, 2001.

14. Calderon, Thomas G., John J. Chen and Michael D. Chatham, "An Examination of the Current State of Accounting Information Systems Education," The Review of Business Information Systems, Vol. 6, No. 2, pp. 29-41, Spring 2002.

15. Gelinas, Ulric J., Jr. and Steve G. Sutton, Accounting Information Systems, Fifth Edition, South-Western College Publishing, Cincinnati, 2002.

16. Hall, James A., Accounting Information Systems, 3rd Edition, South-Western College Publishing, Cincinnati, 2001.

17. Hollander, Anita, Eric L. Denna, and J. Owen Cherrington, Accounting, Information Technology, and Business Solutions, Second Edition, McGraw-Hill/Irwin, New York, 2000.

18. Information Systems Audit and Control Association, Model Curriculum for Information Systems Auditing at the Undergraduate and Graduate Levels, http://www.isaca.org/modelc.htm, 2000.

19. International Federation of Accountants (IFAC), Education Committee, Information Technology In The Accounting Curriculum, International Education Guideline 11, 1995, Revised June 1998.

20. Moscove, Stephen A., Mark G. Simkin, and Nancy A. Bagranoff, Core Concepts of Accounting Information Systems, Seventh Edition, John Wiley \& Sons, New York, 2001.

21. Murthy, Uday S. and S Michael Groomer, Accounting Information Systems: A Database Approach, Ybertext Publishing, Bloomington, Indiana, 1997.

22. Perry, James T. and Gary P. Schneider, Building Accounting Systems Using Access 2000, South-Western College Publishing, Cincinnati, 2001.

23. Romney, Marshall B. and Paul J. Steinbart, Accounting Information Systems, 8th Edition, Prentice Hall, Upper Saddle River, New Jersey, 2000.

24. Wilkinson, Joseph W., Michael J. Cerullo, Vasant Raval and Bernard Wong-On-Wing, Accounting 
Information Systems, Fourth Edition, John Wiley \& Sons, New York, 2000.

25. Wu, Frederick H., "Teaching Accounting Information Systems: A Synthesis," Issues in Accounting Education, pp. 132-145, 1983.

Table 1 The American Institute of Certified Public Accountants' Selected Core Competencies

\begin{tabular}{|c|c|c|c|}
\hline & \multicolumn{3}{|r|}{ AICPA Functional Competencies } \\
\hline $\begin{array}{l}\text { Item } \\
\#\end{array}$ & Category & $\begin{array}{l}\text { Cat. } \\
\#\end{array}$ & Element \\
\hline 1 & Decision Modeling & 1 & Identifies problems and potential solution approaches \\
\hline 2 & Decision Modeling & 2 & $\begin{array}{l}\text { Uses quantitative techniques to determine relative importance and likelihood of } \\
\text { alternative scenarios }\end{array}$ \\
\hline 3 & Decision Modeling & 3 & Employs model-building to quantify problems or test solutions \\
\hline 4 & Decision Modeling & 4 & Evaluates the cost/benefit of alternative solutions \\
\hline 5 & Decision Modeling & 5 & Organizes and evaluates information, alternatives, cost/benefits, risks and rewards \\
\hline 6 & Risk Analysis & 1 & Identifies risks of negative outcomes (including fraud) \\
\hline 7 & Risk Analysis & 2 & $\begin{array}{l}\text { Evaluates controls that mitigate risk of negative outcomes through prevention or } \\
\text { detection and correction }\end{array}$ \\
\hline 8 & Risk Analysis & 3 & $\begin{array}{l}\text { Assesses and controls unmitigated risks through, for example, designing and applying } \\
\text { tests }\end{array}$ \\
\hline 9 & Reporting & 1 & Prepares reports with objectivity, conciseness and clarity \\
\hline 10 & Reporting & 2 & $\begin{array}{l}\text { Describes work performed and conclusions reached in a manner that enhances the } \\
\text { reports' usefulness }\end{array}$ \\
\hline 11 & Reporting & 3 & Employs appropriate media in report preparation and presentation \\
\hline 12 & Research & 1 & Employs relevant research skills \\
\hline 13 & Research & 2 & $\begin{array}{l}\text { Identifies relevant information such as industry trends, internal performance history, } \\
\text { benchmarks, and best practices }\end{array}$ \\
\hline 14 & Prof. Demeanor & 1 & Conducts oneself with honesty \\
\hline 15 & Prof. Demeanor & 2 & Respects confidentiality \\
\hline 16 & Prof. Demeanor & 3 & Commits to quality and efficiency \\
\hline 17 & Prof. Demeanor & 4 & Manages stress and adapts to unusual demands with composure \\
\hline 18 & Prof. Demeanor & 5 & Objectively considers others' professional criticism or evaluation \\
\hline 19 & Prof. Demeanor & 6 & Adheres to a level of personal appearance appropriate to the environment \\
\hline 20 & Problem Solving & 1 & $\begin{array}{l}\text { Synthesizes novel or original definitions of problems and solutions as circumstances } \\
\text { dictate }\end{array}$ \\
\hline 21 & Problem Solving & 2 & Proposes and evaluates alternative solutions \\
\hline 22 & Problem Solving & 3 & Considers contingencies and future developments \\
\hline 23 & Problem Solving & 4 & Analyzes the impact of potential actions \\
\hline 24 & Problem Solving & 5 & Considers unconventional approaches and solutions to problems \\
\hline 25 & Interaction & 1 & Coaches or mentors in appropriate circumstances \\
\hline 26 & Interaction & 2 & Commits to achievement of common goals when working on a team \\
\hline 27 & Interaction & 3 & Accepts suggestions and guidance of team leaders and other members \\
\hline 28 & Interaction & 4 & Recognizes and accommodates the protocols and expectations of teams \\
\hline 29 & Communication & 1 & $\begin{array}{l}\text { Organizes and effectively displays information so that it is meaningful to the receiving } \\
\text { party }\end{array}$ \\
\hline 30 & Communication & 2 & $\begin{array}{l}\text { Places information in appropriate context when listening, reading, writing and } \\
\text { speaking }\end{array}$ \\
\hline 31 & Communication & 3 & Selects appropriate media for dissemination or accumulation of information. \\
\hline
\end{tabular}




\begin{tabular}{|c|c|c|c|}
\hline 32 & Project Management & 1 & Determines project goals \\
\hline 33 & Project Management & 2 & Prioritizes and delegates as needed \\
\hline 34 & Project Management & 3 & Allocates project resources to maximize results \\
\hline 35 & Project Management & 4 & Effectively manages human resources that are committed to the project \\
\hline 36 & Project Management & 5 & Effectively facilitates and controls the project process \\
\hline 37 & Project Management & 6 & Measures project progress \\
\hline 38 & Project Management & 7 & Takes corrective action as needed \\
\hline 39 & Project Management & 8 & Sees projects through to completion or orderly transition \\
\hline 40 & Project Management & 9 & Realistically estimates time and resource requirements \\
\hline 41 & Project Management & 10 & $\begin{array}{l}\text { Recognizes situations where prompt and determined actions are needed and responds } \\
\text { accordingly }\end{array}$ \\
\hline 42 & $\begin{array}{l}\text { Leverage } \\
\text { Technology-PC }\end{array}$ & 1 & $\begin{array}{l}\text { Exchanges information using appropriate communication technologies such as e-mail, } \\
\text { discussion boards and video-conferencing }\end{array}$ \\
\hline 43 & $\begin{array}{l}\text { Leverage } \\
\text { Technology-PC }\end{array}$ & 2 & Explores new technologies and their application to business and accounting scenarios \\
\hline 44 & $\begin{array}{l}\text { Leverage } \\
\text { Technology-PC }\end{array}$ & 3 & $\begin{array}{l}\text { Acquires skills through technology-based learning modules when available and } \\
\text { appropriate }\end{array}$ \\
\hline 45 & $\begin{array}{l}\text { Leverage } \\
\text { Technology-PC }\end{array}$ & 4 & $\begin{array}{l}\text { Addresses privacy, intellectual property rights and security issues related to electronic } \\
\text { communications }\end{array}$ \\
\hline 46 & $\begin{array}{l}\text { Strategic/Critical } \\
\text { Thinking }\end{array}$ & 1 & Articulates the principles of the strategic planning process \\
\hline 47 & $\begin{array}{l}\text { Strategic/Critical } \\
\text { Thinking }\end{array}$ & 2 & $\begin{array}{l}\text { Identifies strengths, weaknesses, opportunities, and threats associated with a specific } \\
\text { scenario, case, or business activity }\end{array}$ \\
\hline 48 & $\begin{array}{l}\text { Strategic/Critical } \\
\text { Thinking }\end{array}$ & 3 & Transfers knowledge from one situation to another \\
\hline 49 & $\begin{array}{l}\text { Strategic/Critical } \\
\text { Thinking }\end{array}$ & 4 & $\begin{array}{l}\text { Analyzes and prepares strategic information (e.g., market share, customer satisfaction, } \\
\text { competitor actions, product innovation, etc.) }\end{array}$ \\
\hline 50 & $\begin{array}{l}\text { Leverage } \\
\text { Technology-BP }\end{array}$ & 1 & Recognizes commonly used information architectures \\
\hline 51 & $\begin{array}{l}\text { Leverage } \\
\text { Technology-BP }\end{array}$ & 2 & Recognizes business opportunities and risks associated with electronic commerce \\
\hline 52 & $\begin{array}{l}\text { Leverage } \\
\text { Technology-BP }\end{array}$ & 3 & Mines electronic data sources for business and industry information \\
\hline 53 & $\begin{array}{l}\text { Leverage } \\
\text { Technology-BP }\end{array}$ & 4 & Uses technology to develop and present strategic information \\
\hline
\end{tabular}


Table 2 Comparison of Topics and Degree of Coverage in the Textbook Reviewed

\begin{tabular}{|c|c|c|c|}
\hline Top 10 topics listed by the AIS Educators (2001) & Score: 5 highest & Number of pages up to: & Number of texts: \\
\hline Data Flow Diagrams & 3.55 & 15 & 8 \\
\hline Document Flowcharts & 3.47 & 16 & 7 \\
\hline Systems Flowcharts & 3.66 & 16 & 6 \\
\hline Entity Relation Diagrams & 3.85 & 1 & 2 \\
\hline REA Model & 3.34 & 36 & 7 \\
\hline Review of Accounting Cycle & 3.77 & 51 & 11 \\
\hline Transaction Cycles & 4.21 & 17 & 4 \\
\hline Computer-based Practice Set & 3.63 & - & - \\
\hline Systems Analysis & 3.47 & 27 & 7 \\
\hline Systems Design & 3.34 & 22 & 6 \\
\hline Emerging AIS Topics Listed by Educators & $\%$ cover & & \\
\hline Database Design & 98 & 22 & 9 \\
\hline Internal Control & 98 & 27 & 8 \\
\hline Electronic Financial Reporting & 93 & 3 & 2 \\
\hline Electronic Audit Trail & 91 & 70 & 9 \\
\hline Enterprise Resource Planning & 91 & $23^{*}$ & 4 \\
\hline Business Process Redesign & 89 & 5 & 4 \\
\hline Disaster Recovery & 89 & 3 & 5 \\
\hline E-Business & 89 & 6 & 6 \\
\hline XBRL & 89 & 5 & 2 \\
\hline \multicolumn{4}{|l|}{ Other Emerging AIS Topics } \\
\hline Digital Subscriber Line & & 0 & \\
\hline Speech Recognition & & 0 & \\
\hline Internet Telephony & & 0 & \\
\hline Knowledge Management & & 10 & 3 \\
\hline Web Trust, ISP Trust, Sys Trust & & 2 & 4 \\
\hline
\end{tabular}

* In one textbook a vendor's software methodology is used to describe cycles in 180 pages.

Notes 